\title{
Long way home \\ The life history of Chinese-Indonesian migrants in the Netherlands ${ }^{1}$
}

\author{
YUMI KITAMURA
}

\begin{abstract}
The purpose of this paper is to trace the modern history of Indonesia through the experience of two Chinese Indonesians who migrated to the Netherlands at different periods of time. These life stories represent both postcolonial experiences and the Cold War politics in Indonesia. The migration of Chinese Indonesians since the beginning of the twentieth century has had long history, however, most of the previous literature has focused on the experiences of the "Peranakan" group who are not representative of various other groups of Chinese Indonesian migrants who have had different experiences in making their journey to the Netherlands. This paper will present two stories as a parallel to the more commonly known narratives of the "Peranakan" experience.

KEYWORDS

September 30th Movement; migration; Chinese Indonesians; cultural revolution; China; Curacao; the Netherlands.
\end{abstract}

\section{INTRODUCTION}

The purpose of this paper is to trace the modern history of Indonesia through the experience of Chinese Indonesians who migrated to the Netherlands after World War II. The study of overseas Chinese tends to challenge the boundaries of the nation-state by exploring the ideas of transnational identities

1 Some parts of this article are based on the rewriting of a Japanese article: Kitamura, Yumi. 2014. "Passage to the West; The life history of Chinese Indonesians in the Netherlands" (in Japanese), Chiiki Kenkyu 14(2): 219-239.

YUMI KITAMURA is an associate professor at the Kyoto University Library. Since 2005, she has been working on the contemporary history of Chinese Indonesians. Her recent works include "Chinese in the linguistic landscape of Jakarta; Language use and signs of change", in: Keith Folcher, Mikihiro Moriyama, and Manneke Budiman (eds), Words in motion (Singapore: National University of Singapore Press, 2012); Re-creating culture of Chinese Indonesians in the Post-Suharto era (in Japanese, Tokyo: Akashi Shoten, 2014). Her current research interest is in Roman Catholic charismatic renewal movements in Indonesia. Yumi Kitamura can be contacted at: kitamuray9@gmail.com.

(C) 2017 Faculty of Humanities, Universitas Indonesia

YUMI KITAMURA | DOI: 10.17510/wacana.v18i1.572. 
(for example, Ong 1999 and Ang 2001). However, the life stories introduced in this paper examine the power of the nation-state and the significance of its boundaries to individual lives at different times during the history of Indonesia.

These life stories were part of intensive interviews conducted with twenty informants (Table 1) in the Netherlands from January to March 2011 and September 2013. The research project eventually developed into a co-research project $^{2}$ and more interviews were conducted with Chinese Indonesians who moved to Hong Kong, Malaysia, and Taiwan, in an effort to understand the wider trends of migration among Chinese Indonesians as a consequence of the socio-political conditions in Indonesia.

\begin{tabular}{cccc}
\hline YEAR & M & F & TOTAL \\
\hline $1940 s$ & 2 & 3 & 5 \\
\hline $1950 s$ & 2 & 4 & 6 \\
\hline $1960 s$ & 2 & 3 & 5 \\
\hline $1970 s$ & 3 & 0 & 3 \\
\hline $2000 s$ & 0 & 1 & 1 \\
\hline Total & 9 & 11 & 20 \\
\hline
\end{tabular}

Table 1: Decade informants in the Netherlands left Indonesia.

There are five major events which relate to the re-migration of Chinese Indonesians after World War II. These are: (1) the Indonesian War of Independence between 1945-1949; (2) the establishment of the People's Republic of China in 1949; (3) Presidential Decree No. 10 in 1959, which prohibited foreign nationals to run small businesses at any administrative level below that of a district; (4) the September 30th Movement in 1965 which shifted the country's policy from pro- to anti-communism; and (5) the antiChinese riots in major Indonesian cities in May 1998. Along the way, many Chinese Indonesians decided to leave the country to secure their lives were safe or to seek fresh opportunities. Their destinations varied from period to period, including the Netherlands, Germany, China, Taiwan in earlier years, then, Singapore, Australia, and the United States in more recent years.

For Chinese Indonesians in the Netherlands, factors 1, 3, and 4 have been the major factors in their migration. In terms of numbers, however, factors 2 and 3 have been the most significant in terms of the number of Chinese Indonesians migrating to China. Factor 3 especially resulted in the migration of approximately 100,000 persons to Mainland China in the early 1960s. Many of these "returnees" were relocated to state-run Overseas Chinese farms set up by the Chinese government in southern provinces of China such as Guangdong, Guangxi, Fujian and Yunnan. There were a total of 51 farms by 1966 (Peterson 2012). 
Two major outbursts of anti-Chinese sentiment, factors 4 and 5 catalysed the migration of many Chinese Indonesians to various destinations. The difference between the two was that the migration triggered by the September 30th Movement, continued until the 1970s as it was followed by the longlasting authoritarian regime of Suharto. In contrast, many of those who migrated after May 1998 went back or resumed their activities in Indonesia after the country was democratized with the fall of Suharto.

\section{Chinese IndONESIANS IN THE NeTHERLANDS}

The Netherlands today is well known to be a country with large groups of immigrants from various backgrounds. Approximately over 20 percent of the entire population of 16,979,120 consists of immigrants and their descendants (CBS 2016). Among them, immigrants from Asia and their descendants number approximately 775,000 persons, among whom the roughly 370,000 persons from Indonesia constitute the largest group (CBS 2016). Although there are no exact figures for the number of Chinese Indonesians and their descendants, an estimate says that approximately 18,000 Chinese Indonesians and their descendants are residing in the Netherlands (Rijkschroeff, The Gwan Tjaij, and Verlaan 2010: 155).

\begin{tabular}{|l|r|r|r|}
\hline & From Indonesia & To Indonesia & Immigration surplus \\
\hline 1945 & & & -0.4 \\
\hline 1946 & 69.3 & 5.4 & 63.9 \\
\hline 1947 & 22 & 23.4 & -1.4 \\
\hline 1948 & 17.6 & 29 & -11.4 \\
\hline 1949 & 16.5 & 23.1 & -6.6 \\
\hline 1950 & 55.9 & 9.1 & 46.7 \\
\hline 1951 & 30.3 & 9.8 & 21.5 \\
\hline 1952 & 16.2 & 8.9 & 7.3 \\
\hline 1953 & 14.2 & 6.3 & 7.8 \\
\hline 1954 & 17.2 & 5.6 & 11.8 \\
\hline 1955 & 24 & 4.5 & 19.5 \\
\hline 1956 & 18.3 & 5.1 & 13.2 \\
\hline 1957 & \pm 16.2 & 4.4 & \pm 11.8 \\
\hline
\end{tabular}

Table 2. Number of persons arriving from or leaving for Indonesia, entered into or written off population registers in Holland (in thousands) (Kraak 1958: 29).

The large waves of migration to the Netherlands began after World War II with the flow of Dutch and Eurasian returnees and Moluccan repatriates who had fought on the colonial side against the Indonesian Republic during the Indonesian War of Independence (De Boer-Lasschuyt 1960). Approximately 300,000 persons fled from Indonesia to the Netherlands between 1945 and 1956 (Kraak 1958; see Table 2 above). The last wave of repatriation occurred when 
the Sukarno implemented the nationalization policy toward Dutch plantations and enterprises following the breakdown of the negotiation between Dutch and Indonesian government over the sovereignty of Western New Guinea in 1957 (De Boer-Lasschuyt 1960). The migrants and repatriates from Suriname followed this wave.

Like many other European countries, during the years of reconstruction after the devastation of the World War II between the 1950s to the 1960s, the Dutch government opened its doors to guest workers from other West European countries such as Greece, Spain, and Portugal (Ersanilli 2007). This scheme was eventually expanded to include countries such as Morocco, Turkey, and former Yugoslavia in the 1970s (Ersanilli 2007). However, in recent years, the higher crime rates among the second-generation Muslim immigrants in large cities, in which migrants and their descendants contribute over the half of the population, has caused an upswing in anti-migrant sentiments (Ersanilli 2007).

In the case of Chinese Indonesians, the history of migration to the Netherlands can be traced back to the early-twentieth century when the number of Chinese Indonesian students seeking opportunities for higher education began to increase (Li 1998, 2013). Prior to the establishment of Dutch schools for Chinese and their descendants (Hollandsche Chineesche School or HCS) in the Netherlands Indies in 1908, the opportunities for Chinese Indonesians to be educated in Dutch were limited to missionary schools; with the exception of the small number of children admitted to the schools for Europeans (Govaars 2005: 39-45, 69-71).

The Dutch colonial government established HCS to prevent Chinese Indonesians from being influenced by Chinese nationalism through the establishment of Chinese educational institutions which spread rapidly throughout the Netherlands Indies after the founding of the Tiong Hoa Hui Koan or THHK in Batavia in 1901. The THHK was the first modern school set up by the Chinese community with the help of international Chinese diasporas in other Asian countries. Education was given in both Mandarin and English, with the focus on Confucian moral education.

In 1927, the Dutch government also established Malay schools for relatively lower class Chinese Indonesians, but many Chinese Indonesians preferred to send their Children to the HCS which would give them more opportunities in colonial society (Govaars 2005: 143-170). By the 1930s, the Dutch-educated Chinese Indonesians exceeded the Dutch-educated non-Chinese in number, even though their Chinese descendants accounted for only two percent of the total population (Lohanda 2002: 76).

In 1911, the first Chinese Indonesian (Netherlands Indies) student group, the Chung Hua Hui, was set up by twenty students in Amsterdam, Leiden, Rotterdam, and Wageningen (Li 1998, 2013; Stutje 2015). The Chung Hua Hui was separate from the Perhimpunan Indonesia, the organization of nonChinese students from Indonesia. Apart from social activities, the Chung Hua Hui also operated its own international agenda influenced by its own 
Chinese diaspora concerns. For instance, it joined in a protest against the Japanese occupation of China during the Paris Peace Conference in 1919 (Stutje 2015: 525). As the number of the Chinese Indonesian students increased, membership in the Chung Hua Hui had reached 150 by 1930, many of whom were initially from the Faculty of Law of Leiden University, but they were subsequently later joined by students of medicine in Amsterdam, technical studies in Delft and economics in Rotterdam (Stutje 2015: 521).

The second wave of Chinese Indonesian migrants to the Netherlands occurred around about the same period as the wave of returnees during and after the Indonesian War. Because the socio-economic structure remained under the control of Dutch firms, the number of incoming students increased (Li 1998: 168-169). Many of the informants interviewed by the author were former students who had arrived at this time, and eventually decided not to go back to Indonesia on account of the political turmoil of the 1960s. Besides the students seeking higher education, there were also Chinese Indonesian descendants who joined the repatriation programme provided by the Dutch government. $^{3}$

Many of the Chinese Indonesians who joined the repatriation programme experienced difficulties in establishing themselves in Dutch society both economically and socially. Their experiences share more commonalities with Eurasians who repatriated around the same time. On the contrary, the Chinese Indonesians who originally came as students had a relatively smooth start because of their language skills, social status, and the network among themselves in Indonesia. In present-day Dutch society, the Chinese Indonesians are often categorized as "Peranakan". The term "Peranakan" originally meant people of Chinese descent born in Indonesia, often of mixed blood and inheriting both Chinese and Javanese culture. However, in the Netherlands the term "Peranakan" is more of an identifier to ethnicize themselves as a ethnic group separate from non-Chinese Indonesians as well as the Chinese from Mainland China and Hong Kong, and the majority of "Peranakans" are former students.

This group of "Peranakan" in the Netherlands has contributed to the common image of Chinese Indonesian immigrants as highly educated professionals, working as doctors, dentists, academics or pharmacists and integrated into Dutch society without too many problems. ${ }^{4}$ Certainly in terms of their professional lives, they were very well integrated, but in terms of their personal lives, they remained within the circle of "Peranakan". For example, many of the first generation "Peranakan" married within their group, and it was only in the second generation that they intermarried with the Dutch. In contrast, the Chinese Indonesians the author met who migrated

\footnotetext{
3 Based on author's interview in January to March 2011.

4 There was a tendency for the choice of professions preferred by Chinese Indonesian families, with a strong preference for medical doctor and pharmacist. For example, a magazine for pharmacists, Farma Magazine, featured interviews with Chinese pharmacists in January 2011. Among seven Chinese pharmacists, six were from Indonesia.
} 
to the Netherlands through the repatriation programme married their Dutch partners from the first generation.

In 1980s, "Peranakan" social clubs or associations were formed by retired "Peranakan" Chinese Indonesians in various cities in the Netherlands, for instance, Vereniging Inisiatip in Den Haag (founded in 1982), Lin Yi Hui in Amstelveen (1985), Hua Yi Xie Shang Hui in Utrecht (1987), and De Vriendschap in Amstelveen (1989). In these "Peranakan" associations, they shared not only social activities but also an interest in Chinese-Indonesian culture as well as in the culture and history in Mainland China. Ang describes how, after they adopted to life in the Netherlands, "Peranakans" began to "reethnicize" or organized themselves under a Chinese diaspora identity in the 1980s (Ang 2001: 31). Ang points out that the strong influence of Chineseness inspired them to seek out their cultural roots in China, even though they did not speak Chinese and they wanted to retain identities separate from Mainland or Hong Kong Chinese (Ang 2001: 31).

Finally, the third wave of Chinese Indonesian migration occurred after the September 30th Movement in Indonesia (Li 1998: 168-189, 2013: 146). Among the 10,000 Chinese Indonesians who left Indonesia at this time, at least 5,000 were estimated to have escaped to the Netherlands (Li 2013: 146) As we shall see in the life-stories below, the cases of migration related to the September 30th Movement include not only immediate and direct migration from Indonesia to the Netherlands, but also a gradual migration after leaving Indonesia. Furthermore, many of the former students who were originally planning to go back to Indonesia upon the completion of their studies decided to stay in the Netherland in the wake of the regime change and political instability after the September 30th Movement.

\section{Migration DURING THE POSTCOLONIAL PROCESS}

As has been examined in earlier literature (Li 1998, 2013; Blussé 1998), a large number of Chinese Indonesians had chosen the Netherlands to pursue their higher education since the beginning of the twentieth century, and this trend continued after World War II. In many cases, more than one child from the same family was sent to the Netherlands. For example, M (born in Makassar in 1942) was sent to the Netherlands in 1951 at the age of ten with her brother and sister, who were about to commence their higher education. M eventually became a university professor in the Netherlands, and her sister and brother settled down in Germany and the United States respectively, after having completed their higher education in the Netherlands.

It should be noted that some Dutch-educated Chinese Indonesian elites had a strong desire to contribute their skills to Indonesia, or even to China. In the case of M's sister, after marrying a man who graduated from medical school in Amsterdam, the couple first returned to Indonesia in 1957. However, being disappointed by the anti-Chinese sentiments in 1965, M's brother-in-law took his family to China that year in the hope of finding ways to contribute to China. Unfortunately, at that time China was moving towards the Cultural 
Revolution and the family failed to find its feet there. In the end, the family returned to Europe and settled in Germany.

Besides migration related to educational opportunities, there were also a number of Chinese Indonesians who joined the migration offered in the repatriation programmes for Dutch citizens including Eurasians and for the Royal Netherlands East Indies Army (KNIL) members and its Ambonese auxiliaries who fought to resume Dutch control during the Indonesian War in 1945 to 1949. The life-history of G gives another insight into the Chinese Indonesian migration of the post-war period.

\subsection{ChildhoOd STORY OF G}

$\mathrm{G}$ is a mixed-blood Chinese Indonesian born in Malang in 1939. His biological father was sent to Myanmar for the construction of the Burma Railway during the Japanese occupation and divorced his mother. Because his stepfather was working for the Dutch electronics company, Algemeene Nederlandsche Indische Electriciteit Maatschappij (ANIEM which later became Perusahaan Listrik Negara or PLN), he and his family remained in the protection camp for the Dutch between 1945 and 1947.

Under Netherlands Citizenship Act S.296 of 1910, local-born Chinese Indonesians as well as "inhabitants" of the Netherlands Indies were given status of Dutch subjects during the colonial period (Willmott 2009: 31, 8990). In 1949, after the recognition of the Independence of Indonesia, the Dutch government encouraged people to take Indonesian citizenship in "the 70 million Dutch subjects", 5 but those who were not able to confirm their nationality were given a two-year period to make their choice (Van Oers, De Hart, and Groenendjik 2013: 10-11). The Chinese Indonesians were also eligible for Chinese citizenship if they decided not to claim Indonesian citizenship (Wilmott 2009: 41-51). G and his family opted for Dutch citizenship.

\subsection{LEAVING FOR THE NETHERLANDS}

G was educated in a Dutch school for Indonesians. In 1956, while he was still at high school, G obtained information from his friends from another school about repatriation boats to the Netherlands and decided to apply for the repatriation of his family. Surveying the conditions in Indonesia, G did not foresee a bright future for himself there. He went to the Dutch embassy to apply for repatriation for the entire family without consulting with his parents prior to the application.

In 1950s, Indonesia was unstable both politically and economically. In 1955, the first democratic election was held, but the result of the election deepened feelings of dissension among people from different regional, religious or political backgrounds. In addition, the transformation of the economic structure from that of the colonial period to that of an independent state was not very successful. As a young man, $\mathrm{G}$ saw these conditions presaged problems for the future of the country. 
Although all the members of G's family were allowed to leave the country, his parents decided to send $G$ and his three siblings on ahead to the Netherlands. Prior to their repatriation, one of G's aunts on his mother's side had migrated to the Netherlands because her husband was a member of KNIL.

In November 1956, G, his elder brother and sister, and a young brother embarked on one of the repatriation boats, the Sibajak, and arrived in the Rotterdam on 9 December $1956 .{ }^{6}$ The Sibajak was a large cruise ship with facilities which included a movie theatre and shops. All clothes and meals were provided free of charge. The boat first called at Jakarta, then headed to Rotterdam via the Cape of Good Hope, South Africa. G recalled the voyage on board the Sibajak as a pleasant time. Besides him and his siblings, the friend who had shared the information about the repatriation programme was also on board.

After arriving in the Netherlands, children without parents were assembled in an institution in The Hague. There, a government official took them shopping for new clothes and gave them some pocket money. After remaining there two months, $\mathrm{G}$ and his siblings were sent to Roman Catholic host families in accordance with their faith. G's elder brother was sent to Eindhoven and the remaining three were accepted by a family in Maastricht.

G's story confirms the report published by the Dutch Ministry of Social Affairs in 1958. Besides taking care of the children not accompanied by their parents or orphans, the Ministry also organized a special repatriation programme for the elderly (Ministry of Social Work 1958). According to De Boer-Lasschuyt, the staff members from the Ministry of Social Affairs involved in the repatriation program were overall receiving the newcomers from Indonesia with sympathy and warm attitude (De Boer-Lasschuyt 1960:33).

\subsection{CAREER DEVELOPMENT AND FAMILY REUNION}

After settling in Maastricht, $G$ was confronted with hardships which he recalled with bitterness. After moving to the house of the host family in Maastricht, G and his sister were asked to go to work. Only his little brother could continue his schooling. G decided to apply for vocational school, which provided a monthly payment, and then transferred to a technical secondary school (MTS) in Venlo before he was conscripted into military service.

Finally, in 1963, G's mother and stepfather moved to the Netherlands and the family was reunited in Venlo. His mother was aged 40 and his stepfather was 52 when they moved there. G began to work in a factory in Maastricht while attending higher technical school (HTS). However, he had to drop out of school after a year because he was transferred to new division of the factory. He worked three times as hard as his Dutch co-workers and had been

6 The Dutch government provided ships to transport people from Indonesia to the Netherlands from 1945 to 1964 and the Sibajak was the name of one of the ships. According to the list of boats [Retrieved from: http://home.planet.nl/ oost2767/index.html, accessed on 2-1-2017], the Sibajak left Surabaya on 5 November and carried 570 passengers to Rotterdam, arriving there on 9 December 1956. 
promoted to division manager by the end of the year. In 1966, G married a Dutch woman and was blessed with three children.

\subsection{GOING "HOME" TO INDONESIA}

In 1978, G went back to Indonesia for the first time. A year before, G's sister had gone home and found out that their biological father was alive but ill. $\mathrm{G}$ decided to visit Indonesia to meet his biological father, whom he had not seen for a very long time. G's father passed away just three months after G's visit. G's mother and stepfather went home three times before they passed away in 2005.

$\mathrm{G}$ is currently living alone since his wife passed away in 2001. G has never told his life history to his children and he only shares his story with the people who have had similar experiences, including his high school friends who also repatriated to the Netherlands.

In his story G describes Indonesia as "tanah air ibu (motherland)" and the Netherlands as "tanah air bapak (fatherland)".

\subsection{REFLECTIONS}

During the early postcolonial period in Indonesia, Chinese Indonesian students continued to apply to Dutch universities to pursue their higher education in the Netherlands, but there were also Chinese Indonesians who chose to be repatriated to the Netherlands, as we have seen in G's story. Although both these types of people might have had a similar lifestyle in Indonesia, their experiences in the Netherlands have run parallel and never intersected. Whereas one contributed to the post-war reconstruction in the Netherlands as a factory worker, the other became a member of the Dutch elite class.

\section{The September 30th Movement and migration}

Not very long after the large-scale migration to China in the early 1960s after the issuance of Presidential Decree No. 1 in 1959, the September 30th Movement and the nationwide massacre and the purge of (alleged) communists in 1965 led to another wave of migration. The fall of Soekarno and the rise of Suharto swung Indonesia's political environment from the left to that of an anticommunist country. Three chief patterns of migration can be associated with the September 30th Movement, namely: the migration of victims and their family members; people exiled after having studied or worked in socialist countries during the Soekarno period; and those who escaped the country by choosing to study abroad. The story of $\mathrm{N}$ falls into the first category.

In the second instance, Hill (2010) and Amin (2015) elucidate the passage of these diplomats and students after the September 30th Movement and Dragojlovic (2010) describes in detail the experiences of former Balinese students in the Netherlands. All diplomats and students who were abroad at the time of the coup were instructed to undergo a screening process to determine their loyalty (Hill 2010: 31-32). Those who refused to be screened were provided with a travel document valid only for a return to Indonesia 
(Hill 2010: 31-32). However, in the impassioned atmosphere which prevailed at that time, many of those who had been sent to socialist countries were afraid of being arrested upon their return to Indonesia and decided to remain in the Eastern Bloc. Hill estimates about 500 of these exiles managed to escape to the Netherlands. A few of my informants were also former students who had studied in China and Albania. In both cases, they moved to the Netherlands in the 1970s to be reunited with their families.

Soon after the September 30th Movement, the Indonesian exiles in China were caught up in the Cultural Revolution. Initially, they were isolated from the Chinese population and kept under guard in the Friendship Hotel (Hill 2010: 34). This isolation was enforced after the suspension of diplomatic relations between China and Indonesia (Hill 2010: 34). They were eventually relocated to Nan Chang (Hill 2010: 34).

The third case includes both students who were already studying abroad and told not to go back by the family and those who were sent overseas by family members to escape the turmoil in Indonesia.

\subsection{STORY OF N BEFORE LEAVING INDONESIA}

Among the life history of victims of September 30 Movement who fled to the Netherlands, the following story of $N$ portraits not only the condition of Chinese Indonesians after the incident but gradual transition from the colonial world to the Indonesia after the independence.

$\mathrm{N}$ was born in Medan in 1928. Both her parents had been given a Dutch education. After World War II, when the Indonesian War of Independence broke out, her family applied to be evacuated to a protection camp for Dutch citizens to ensure the safety of their lives because they felt their lives were in danger. Like many other Chinese Indonesians who had been educated in Dutch, N's father was working as a construction engineer in Dutch sugar plantation company, Handelsvereeniging Amsterdam, in Medan. His employment meant that the family supported the Dutch during the Indonesian Independence War. In their application, the family emphasized their concerns about safety of life and limb as well as ensuring the education of $\mathrm{N}$ and her elder sister in Dutch. Eventually they were allowed to move to the camp on condition they shared a house with another family.

In 1946, N's elder sister left to pursue her higher education in the Netherlands on a boat for Dutch returnees. N, on the other hand, went to pursue her tertiary education in the field of pharmacy in Bandung in 1950. In 1958, she married a senior student who was a Chinese Indonesian from Semarang at the same university. Struggling with the change of the language of instruction in higher education from Dutch to Indonesian, $\mathrm{N}$ was unable to complete her degree. $\mathrm{N}$ says that, although she had no problem speaking Indonesian in everyday life or reading the newspaper, the language used in higher education was too difficult to understand. Her husband, on the other hand, was able to obtain his degree in pharmacy. When they married, they moved to Medan and were eventually blessed with two children. 
The September 30th Movement completely changed the destiny of the family. One night in 1966, the police escorted by local people came to their house and arrested her husband on suspicion of being a communist because his name was listed as a part-time lecturer at one of the schools run by leftists. $\mathrm{N}$ suspects that to the arrest was because the local people were jealous of his friend who held a high position on the rubber plantation and had asked him to become a part-time lecturer; he was automatically arrested when his friend was named as communist.

That night, $\mathrm{N}$ immediately called her tennis friend who was a general in the Indonesian Army and asked him why her husband had been arrested. Although the general did not give a clear response, somehow her husband was released within 24 hours, but it took several years for his friend to be released.

This incident strengthened the resolution of $\mathrm{N}$ and her husband to leave the country as soon as possible. Eventually, in 1968 someone from the same school in Bandung called their attention to a job opening for a pharmacist in Curaçao. The family and N's sister-in -law packed its bags and left for Curaçao. Before departure, the family sold all its property and was given the address of an agent in Singapore who could transfer its money once they were settled in Curaçao. Consequently, the family travelled to Singapore to meet the agent, then on to Amsterdam before setting off to Curaçao. To N's surprise, When the family visited his house the agent showed up dressed only in an undershirt and short pants, not looking at all like a professional person. N's sister-in-law also migrated with the family.

\subsection{Leaving For CuRAÇAO}

The family eventually settled in Curaçao, where were three other Chinese Indonesian families at that time. Curaçao was a multi-ethnic society consisting of migrants from Europe, Suriname, and Indonesia as well as the descendants of slaves. There was also a social cultural organization called Indische Vereniging Curaçao (IVC) for people from Indonesia, including Euro-Asians, where $\mathrm{N}$ and her family felt at home.

Being a Protestant family in a country where the majority were Roman Catholic, the family became closer to the Dutch community, including employees of the Dutch oil company, Shell. N's children were sent to a Protestant school where all teaching materials were sent from the Netherlands.

Eventually, N's father joined the family from Indonesia. N's father was 69 years of age when he travelled to Curaçao after having visited all his relatives in Indonesia, and he died there at the age of $80 . \mathrm{N}^{\prime}$ s sister-in-law moved to the Netherlands with the family in 1986.

\subsection{ChANGING CITIZENSHIP}

$\mathrm{N}$ and her family left Indonesia with Indonesian passports. After five years, the family obtained Dutch citizenship. It was in those five years that the Indonesian embassy in Venezuela, which covered Curaçao, ordered them to change their name from a Chinese to Indonesian one. However, when it obtained Dutch 
citizenship, the family was able to resume its original name. By this time, $\mathrm{N}$ and her husband had no hesitation about changing their citizenship.

\subsection{LEAVING FOR THE NETHERLANDS}

After working at the Wilhelmina Pharmacy for three years, N's husband left for Groningen for a thirteen'month training programme which would allow him to obtain a Dutch pharmacology certificate, so that they could eventually move to the Netherlands when their children began their tertiary education. Aware that there was no institution for higher education in Curaçao at that time, the family was preparing to immigrate to the Netherlands. When he returned, N's husband worked as a pharmacy audit officer until he eventually became a pharmacist in Shell.

After both children had left for Amsterdam to pursue their higher education, N, her husband and his sister followed them to the Netherlands. N's husband successfully purchased a pharmacy in Rotterdam. Both her children married Dutch spouses. In 1995, they moved to Amsterdam and both N's husband and his sister passed away there.

$\mathrm{N}$ is currently living alone with the help of carers, not too far away from her daughter. At the weekends, she goes to church or joins in the activities at one of the "Peranakan" associations. She also enjoys talking to her old friends on Skype.

This unique passage of $\mathrm{N}$ and her family from Indonesia to Curaçao, then to the Netherlands was made possible by the social capital they had acquired in the Dutch colonial period. Although N's experience is quite unique, she has been well integrated into "Peranakan" society since her migration to the Netherlands.

On the other hand, broadly speaking, exiles tend to form their own community and prefer to associate among themselves, whether they were Chinese Indonesian or Indonesians of other ethnic background and the ethnic boundaries of Chinese Indonesians is not a central issue in this group. ${ }^{7}$

\section{MigRATION AFTER THE MAY 1998 INCIDENT}

Although the majority of the earlier Chinese Indonesian migrations went to China, Taiwan, and the Netherlands because of historical associations, migrations after May 1998 indicate a shift in a preference for English-speaking countries such as Singapore, Malaysia, and the USA. This change is attributable to the shift of location for higher education and to the business concerns of the families. Penang where there are large numbers of female Chinese Indonesians who were able to escape from Medan because of their ability to speak Hokkien forms an exception. Some of them run businesses in globalized markets, for instance, as medical tourism agents for Indonesian patients and Indonesian housemaid agencies. These new patterns of migration among Chinese Indonesians in the globalized economy should be examined in more depth. 


\section{CONCLUSION}

In this paper, life-stories of Chinese Indonesians who moved to the Netherlands in 1950s and 1970s have been examined. In both periods, although incoming students were a large source of subsequent migrants, other migration routes were also followed. These different types of migrant groups present contrasting processes of identity formation and positioning in Dutch society. While many of former students from 1950s eventually reorganized themselves as a unique ethnic group, for instance, "Peranakans", the repatriated Chinese Indonesians wove themselves into Dutch society through by marriage and work. This did not give them much space in which to share their unique experiences. Another contrast or parallel can be seen among "Peranakans" and former exiles. Former exiles keep a close relationship with one another on the basis of their shared experiences, and they tend not to move along the ethnic boundaries like the Peranakan do. The exiles also tend to retain a stronger identity as Indonesians, reflecting their original intention to serve their country which immediately contests with their sorrow and bitterness towards Indonesia.

The long passage home for Chinese Indonesians continued after the democratization of Indonesia in 1998. Many Chinese Indonesians in the Netherlands follow developments in Indonesia closely.

Finally, the importance of paying closer attention to the complexity of individual lives, which are more easily upset, needs to be stressed when studying migration whether it be historical or contemporary. In an examination of a historical study, it is a powerful tool by which to reflect on the impact of political agendas on individual lives. In contemporary cases, an individual life-history can suggest various approaches which need to be taken to prevent conflict.

\section{REFERENCES}

Amin Mudzakkir. 2015. "Hidup di pengasingan; Eksil Indonesia di Belanda", Masyarakat dan Budaya 17(2): 171-184.

Ang Ien. 2001. On not speaking Chinese; Living between Asia and the West. London and New York: Routledge.

Blussé, Leonard. 1998. "The ethnic Chinese communities in the Netherlands", in: Wang Ling Chi and Wang Ganwu (eds), The Chinese diaspora; Selected essays; Vol. 2, pp. 148-152. Singapore: Times Academic Press.

Boer-Lasschuyt, Topaas de. 1960. “Euroasian Repatriants in Holland", R.E.M.P. Bulletin; Research Group from European Migration Problems 8(2): 23-45.

CBS. 2016. "Centraal Bureau voor de Statiestiek". [Retrieved from: https:/ / www.cbs.nl/, accessed on 2-1-2017].

Dragojlovic, Ana. 2010. "'Sukarno's students'; Reconfiguring notions of exile, community and remembering", Review of Indonesian and Malaysian Affairs 44(1): 53-81. 
Ersanilli, Evelyn. 2007. "Country profiles Netherlands". [Retrieved from: http:/ / focus-migration.hwwi.de/typo3_upload/groups/3/focus_ Migration_Publikationen/Laenderprofile/CP11_Netherlands.pdf, accessed on 2-1-2017].

Farma Magazine. 2011. Farma Magazine (January).

Govaars, Ming. 2005. Dutch colonial education; The Chinese experience in Indonesia, 1900-1942. Singapore: Chinese Heritage Center.

Hill, David T. 2010. "Indonesia's exiled left as the Cold War thaws", Review of Indonesian and Malaysian Affairs 44(1): 21-51.

Kitamura, Yumi. 2014. "Passage to the West; The life history of Chinese Indonesians in the Netherlands" (in Japanese), Chiiki Kenkyu 14(2): 219-239.

Kraak, J.H. 1958. "The repatriation of the Dutch from Indonesia", R.E.M.P Bulletin; Research Group from European Migration Problems 6(2): 27-40.

Li Minghuan. 1998. "Living among three walls? The Peranakan Chinese in the Netherlands", in: Elizabeth Sinn (ed.), The last half century of Chinese overseas, pp. 167-184. Hong Kong: Hong Kong University Press.

Li Minghuan. 2013. Seeing transnationally; How Chinese migrants make their dreams come true. Hangzhou: Zhejiang University Press.

Lohanda, Mona. 2002. Growing pains; The Chinese and the Dutch in colonial Java, 1890-1942. Jakarta: Yayasan Cipta Loka Caraka.

Ministry of Social Work. 1958. Assistance to persons repatriated from Indonesia. Den Haag: Ministry of Social Work.

Ong, Aiwa. 1999. Flexible citizenship; The cultural logics of transnationality. Durham; Duke University Press.

Peterson, Glen. 2012. Overseas Chinese in the People's Republic of China. London and New York: Routledge.

Rijkschroeff, Boudie, Paul The Gwan Tjaij, and Antoon Verlaan. 2010. Indonesische Cinezen in Nederland. Amsterdam: SWP.

Stutje, Klaas. 2015. “The complex world of the Chung Hwa Hui; International engagement of Chinese Indonesian Peranakan students in the Netherlands, 1918-1931", Bijdragen tot de Taal-, Land-en Volkenkunde 171: 516-542.

Willmott, Donald. E. 2009. The national status of the Chinese in Indonesia 19001958. Jakarta/Kuala Lumpur: Equinox Publishing.

Van Oers, Ricky, Betty de Hart, and Kees Groenendjik. 2013. Eudo citizenship observatory country report; The Netherlands. Florence: European University Institute. 